\title{
FROG OOCYTE in vitro MATURATION TEST AS A METHOD TO INVESTIGATE $\mathrm{Ni}^{2+}$ TOXICITY
}

\author{
Henriks Zenkevičs and Vija Vose \\ Institute of Biology, University of Latvia, Miera iela 3, LV-2169, Salaspils, LATVIA \\ e-mail: zenkevics@email.lubi.edu.Iv
}

Contributed by Henriks Zenkevičs

\begin{abstract}
The ability of gonadotropic hormone (GTH) of sturgeon fish Acipenser güldenstädti Br. to initiate a specific stimulatory effect on grass frog Rana temporaria $L$. oocytes, producing its in vitro maturation, was employed as a method to investigate the effect of nickel ion concentration on test oocytes in a highly sensitive test system, "Oocyte-GTH". Oocytes of four frogs with different hormone sensitivity were used in the investigation. It was shown that $\mathrm{Ni}^{2+}$ at a concentration of $0.1 \mathrm{mg} / \mathrm{L}$ produced a considerable stimulatory effect only in test frog oocytes with low hormonal sensitivity and maturation activity, while a $\mathrm{Ni}^{2+}$ concentration over $0.25 \mathrm{mg} / \mathrm{L}$ caused a significant decrease and produced even total blocking of the hormonal sensitivity and maturation ability of all oocytes, regardless of their initial hormonal sensitivity. The frog oocyte maturation test was shown to be a useful method to assess toxic effect of $\mathrm{Ni}^{2+}$ on water frog reproduction.
\end{abstract}

Key words: $\mathrm{Ni}^{2+}$, frog oocytes, gonadotropic hormone, hormonal effects.

\section{INTRODUCTION}

It has been shown that nickel ions $\left(\mathrm{Ni}^{2+}\right)$, like other heavy metal ions, may have a negative influence on hydrobionts, causing mortality of fish, amphibians and other aquatic organisms (Verriopoulos and Dimas, 1988; Hopfer et al., 1991; Burba, 1999; Brix et al., 2004; Fort et al., 2006; Ololade and Oginni, 2009). $\mathrm{Ni}^{2+}$ has been shown to be genotoxic for South African frog (Xenopus laevis), which was used as an experimental model to investigate the molecular mechanisms of nickel effects (Sunderman et al., 1990; Sunderman, 1993). Also, the negative impact of nickel on reproductive activity, development and growth of various hydrobionts, such as fish (Blaylock and Frank, 1979; Sioson and Herrera, 1995-1996), toads and frogs (Fort et al., 2006) has been shown. Amphibians at their early embrio-larval development stages are particularly sensitive to nickel (Fort et al., 2006), as nickel can cause changes in growth rate, produce malformation and even death of amphibians. Nevertheless, it also known that nickel is a necessary microelement for normal development of some aquatic organisms (Muyssen et al., 2004).

The aim of this study was to apply a highly sensitive and very specific "oocyte-hormone" bio-test system based on the grass frog oocyte in vitro maturation under the influence of sturgeon GTH, as a tool to assess the effect of different $\mathrm{Ni}^{2+}$ test-concentrations on frog oocyte hormone-initiated maturation ability.

\section{MATERIALS AND METHODS}

Highly purified standard sturgeon GTH $\left(\mathrm{M}_{\mathrm{r}}=25 \mathrm{kDa}\right)$ was isolated from acetone-dried pituitary glands according to a standard method (Burzawa-Gerard et al., 1975; Zenkevics, 1992). Oocytes of four grass frogs Rana temporaria L. with different hormone sensitivity and maturation ability were used in the investigation. The frogs were purchased in October 2009 and kept in dark at $5{ }^{\circ} \mathrm{C}$ till mid January, before starting biotests. Oocyte in vitro maturation tests (Thornton, 1971) were performed in three replicates, and the mean values of responses were reported.

In a typical standard set of experiments, portions of 25 fresh test oocytes were incubated for $48 \mathrm{~h}$ at $13{ }^{\circ} \mathrm{C}$ in Petri dishes in Ringer solution $(8 \mathrm{ml})$ containing GTH $(0.5 \mathrm{mg} / \mathrm{L})$ and penicillin $(0.5 \mathrm{~g} / \mathrm{L})$.

To assess the effect of Ni ions on oocyte GTH-stimulated maturation, concentrations of $0.1,0.25,0.5,0.75,1.0$, and $2.0 \mathrm{mg} \mathrm{Ni}{ }^{2+} / \mathrm{L}\left(\mathrm{NiCl}_{2} \cdot 6 \mathrm{H}_{2} \mathrm{O}\right)$ were applied in the standard test medium. A constant GTH concentration of $0.5 \mathrm{mg} / \mathrm{L}$ was used throughout the biotests, and the percentage of the mature test-oocytes was determined in three parallel replicates for each $\mathrm{Ni}^{2+}$ concentration.

The test oocytes used in the experiments were washed fivefold with distilled water, dried at room temperature to constant weight and ashed by $\mathrm{HNO}_{3}$ in the presence of $\mathrm{H}_{2} \mathrm{O}_{2}$. The concentration of $\mathrm{Ni}^{2+}$ in the test oocytes was then deter- 
mined using electrothermal atomic absorptiometer (AAnalyst 600, Perkin Elmer).

\section{RESULTS}

Fresh oocyte portions taken separately from each of the four test-frogs were exposed to GTH in $\mathrm{Ni}^{2+}$-free Ringer solution (standard test). In this standard test medium, the frog oocytes showed different hormone sensitivity and maturation ability (Fig. 1): frog 1(1.2\%), frog $2(15.0 \%)$, frog 3 $(19.0 \%)$ and frog $4(48.0 \%)$. We divided the oocytes into four groups based on their ability to respond to the gonadotropic impact of the hormone with maturation, in order to determine the influence of hormone sensitivity of the oocytes on the response to nickel.

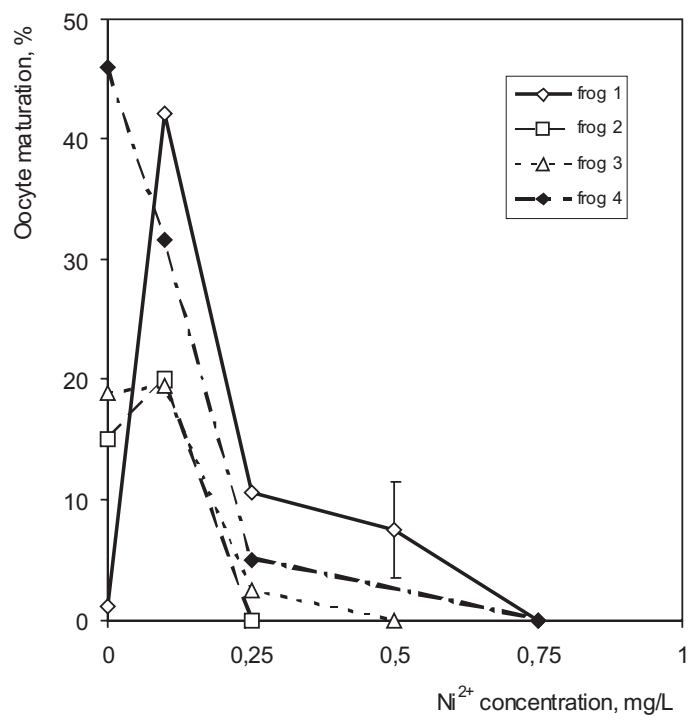

Fig. 1. Hormonal sensitivity of frog oocytes in the test system „oocytehormone" at different $\mathrm{Ni}^{2+}$ content in test medium.

The lowest concentration of $\mathrm{Ni}^{2+}(0.1 \mathrm{mg} / \mathrm{L})$ used produced a considerable stimulatory effect on oocyte maturation activity of frog 1 by about 35 times in comparison with that of the standard (Fig. 1). The oocytes of frog 2 exhibited only a slight increase in maturational activity, within the limits of possible errors, while the activity of the oocytes of frog 3 remained practically unchanged. The activity of frog 4 decreased. A stimulatory effect was also observed at a $\mathrm{Ni}^{2+}$ concentration of $0.25 \mathrm{mg} / \mathrm{L}$, where the oocyte activity of frog 1 increased, while the oocyte activity of frogs 3 and 4 decreased by about $17 \%$ and $41 \%$ correspondingly, in comparison with that of the standard. The oocytes of frog 2 at the same nickel concentration level lacked activity. Progressively increased nickel test concentrations from 0.5 to $2.0 \mathrm{mg} / \mathrm{L}$ produced inactivation of the oocytes of all the tested frogs.

The test results showed (Fig. 1) that exposure of frog oocytes to $\mathrm{Ni}^{2+}$ test concentrations exceeding $0.5 \mathrm{mg} / \mathrm{L}$ significantly decreased oocyte sensitivity to sturgeon GTH and decreased their in vitro maturation ability. Test oocytes that had accumulated over $13 \mu \mathrm{g} \mathrm{Ni}^{2+} / \mathrm{g}$ lost their hormonal sensitivity and maturation ability (Fig. 2).

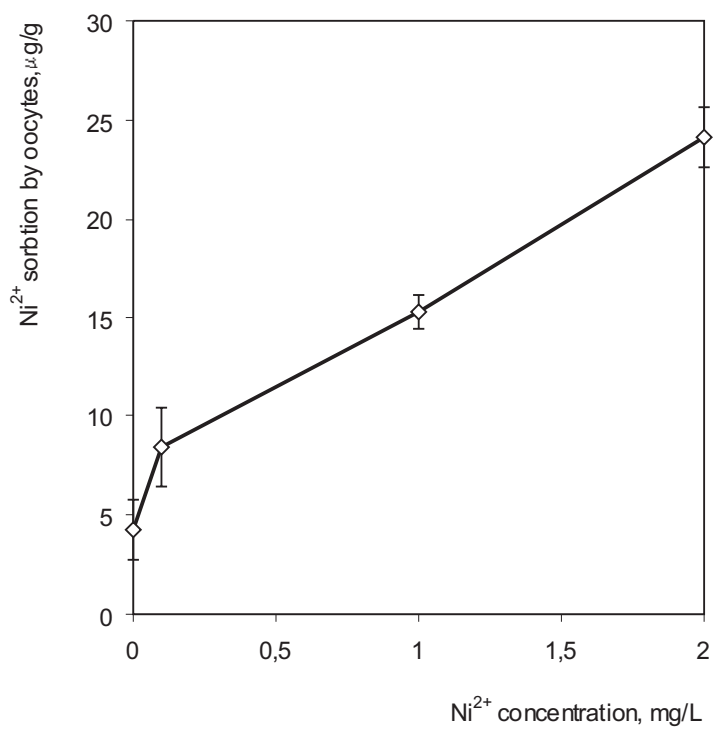

Fig. 2. $\mathrm{Ni}^{2+}$ sorption by frog oocytes at different ion contents in test medium.

\section{DISCUSSION}

In frog embryos nickel uptake occurs through cellular membranes depends on exposure time and nickel ion concentration (Sunderman et al., 1990). $\mathrm{Ni}^{2+}$ can be actively bound by histidyl-containing peptides and other protein structures (Sunderman, 1993) which, having high and specific affinity for nickel, can form complexes with the ion. Transport of nickel ions across cellular membranes can cause modification (complexation) of some regulatory protein structures of vital importance (DNA-proteins), disrupting bioregulation processes and typical biological functions (Sunderman, 1993). On the other hand, nickel ions can be partly sorbed (bound) on the cell membrane by surface-fixed protein functional structures, including protein-like hormone receptors or receptor zones. Gonadotropins and other protein hormones do not translocate into target cells, and their specific hormonal activity occur via receptors located on the surface of the cell membrane (Sairam et al., 1984). Thus, the initial signal of GTH to catalyze intracellular events in the developing oocyte can be sent by the hormone inside the oocyte only after efficient complementary interaction (binding) with its membrane surface receptors.

The test results (Fig. 2) indicated that the oocytes had rather high affinity for $\mathrm{Ni}^{2+}$, and an increase in the ion concentration in the test medium resulted in increased nickel sorption by the oocytes. Test oocytes that had sorbed over $13 \mu \mathrm{g}$ $\mathrm{Ni}^{2+} / \mathrm{g}$ lost their hormonal sensitivity and maturation ability.

A low nickel ion concentration $(0.1 \mathrm{mg} / \mathrm{L})$ significantly increased oocyte GTH sensitivity in frog 1 . A progressive decline in the ability of oocytes to respond to the stimulatory impact of the hormone with maturation occurred at nickel test-concentrations exceeding $0.5 \mathrm{mg} / \mathrm{L}$. The progressive decline of GTH effect on the test oocytes at high nickel concentrations suggests that, most likely, the follicular membrane receptor sites are partly blocked or somehow modified by nickel ions. This may cause a considerable decrease 
in the efficiency of GTH-specific receptor binding with the hormone molecules necessary for the transduction of the hormonal impulse through the membrane receptors inside the oocyte to initiate maturation processes. On the other hand, $\mathrm{Ni}^{2+}$ ions, which have penetrated inside the oocyte by transmembrane diffusion or by transport via $\mathrm{Ca}^{2+}$ channels (Denkhaus and Salnikow, 2002), may interact with the oocyte functional elements, such as adenylate cyclase cycle components and particularly with functional proteins (kinases) and the phosphoprotein system. In this way the hormonal signal effect on the target functional structures inside the oocyte responsible for maturation can be altered or even blocked. Of course, both of these processes may proceed in steps.

The results indicate that low $\mathrm{Ni}^{2+}$ ion concentrations in the test medium ranging from 0.10 to $0.25 \mathrm{mg} / \mathrm{L}$ can cause a stimulatory effect on both oocyte hormone sensitivity and maturation ability. Relatively low $\mathrm{Ni}^{2+}$ concentrations may have a micro-element stimulating normal cell function. Our experiments show that nickel ions at low concentrations $(0.1 \mathrm{mg} / \mathrm{L})$ can produce a stimulatory or inhibitory effect depending on the standard test oocyte hormonal sensitivity exhibited in nickel-free test medium. The effect of $\mathrm{Ni}^{2+}$ on developing frog oocytes very much depends on the ion concentration in water. High $\mathrm{Ni}^{2+}$ concentrations may affect water frog population and their reproduction.

In summary, the frog oocyte maturation test showed that $\mathrm{Ni}^{2+}$ ions may affect regulation of the oocyte-hormone interactions and hormone-dependent reproduction processes in water frogs. $\mathrm{Ni}^{2+}$ may prevent transduction of the hormonal signal from the follicular membrane receptors to the functional target structures inside the oocyte. A pronounced inhibitory effect was shown at nickel concentrations over $0.5 \mathrm{mg} / \mathrm{L}$, suggesting that these concentrations in water may affect aquatic frog communities and their reproduction.

Also, in our earlier publication it was shown that the frog oocyte maturation test was useful as a method to assess humic acid impact on frog reproduction (Zenkevics et al., 2005).

\section{ACKNOWLEDGEMENTS}

This work was supported by the Latvian Council of Science, grant 09.1550 .

We are grateful to Mg. Vita Rudoviča, Department of Analytical Chemistry, University of Latvia, for her kind help in nickel sorption analyses.

\section{REFERENCES}

Blaylock, B.G., Frank, M.L. (1979). A comparison of the toxicity of nickel to the developing eggs and larvae of carp Cyprinus carpio. Bull. Environ. Contam. Toxicol., 21, 132-135.

Brix, K.V., Keithly, J., Deforest, D.K., Laughlin, J. (2004). Acute and chronic toxicity of nickel to rainbow trout Onchorynchus mykiss. Environ. Toxicol. Chem., 23, 2221-2228.

Burba, A. (1999). The design of an experimental system of estimation methods for effects of heavy metals and their mixtures on Daphnia magna. Acta Zoologica Lituanica. 9, 21-29.

Burzawa-Gerard, E., Goncharov, B.F., Fontaine, Y.A. (1975). L’hormone gonadotrope hypophysaire d'un poisson chondrosteen, l'esturgeon Acipenser stellatus Pall. 1. Purification. Gen. Comp. Endocrinol., 27, 289-295.

Denkhaus, E., Salnikow, K. (2002). Nickel essentiality, toxicity, and carcinogenity. Crit. Rev. Oncol. Hematol., 42, 35-56.

Fort, D.J., Rogers, R.I., Thomas, J.H., Hopkins, W.A., Schlekat, C. (2006). Comparative developmental toxicity of nickel to Gastrophrine, Bufo terrestris, and Xenopus laevis. Arch. Environ. Contam. Toxicol., 51, 703-710.

Hopfer, S.M., Plowman, M.C., Sweeney, K.R., Bantle, J.A., Sunderman, F.M. (1991). Teratogenicity of $\mathrm{Ni}^{2+}$ in Xenopus laevis, assayed by the FETAX procedure. Biol. Trace Element Res., 29, 203-216.

Muyssen, B.T.A., Brix, K.V., Deforest, D.K., Janssen, C.R. (2004). Nickel essentiality and homeostasis in aquatic organisms. Environ. Rev., 12, 113-131.

Ololade, I.A., Oginni, O. (2009). Toxic stress of nickel on African catfish, Clarias gariepinus fingerlings. Internet J. Vet. Med., 6. http://www.ispub.com/journal/the_internet_journal_of_veterinary_medicine.

Sairam, M.R., Kato, K., Manjunath, P., Sairam, J., Dobias-Goff, M. (1984). Blockade of gonadotropin action at the receptor. In: Hormone Receptors in Growth and Reproduction. Saxena, B.B. et al. (ed.). New York: Raven Press, 9, 185-199.

Sioson, L.C., Herrera, A.A. (1995-1996). Impact of nickel intoxication on ovarian histology in Oerohromis mossambicus. Science Diliman, 7\&8, 14-21.

Sunderman, F.W. Jr., Mongillo, F.J., Plowman, M.C., Brennan, S.M. (1990). Uptake and release of ${ }^{63} \mathrm{Ni}^{2+}$ by Xenopus embryos during early cleavage stages. Biol. Metals, 2, 214-218.

Sunderman, F.W., Jr. (1993). Search for molecular mechanisms in the genotoxicity of nickel. Scand. J. Work. Environ. Health, 19, 75-80.

Thornton, V.F. (1971). A bioassay for progesterone and gonadotropins based on meiotic division of Xenopus oocytes in vitro. Gen. Comp. Endocrinol., 16, 599-605.

Verriopolos, G., Dimas, S. (1988). Combined toxicity of copper, cadmium, zinc, lead, nickel, and chrome to the copepod Tisbe holothuriae. Bull. Environ. Contam. Toxicol., 41, 378-384.

Zenkevics, H., Klavins, M., Vose,V., Bucena, A. (2005). Humic acid reduces gonadotropin activity and hormonal sensitivity of frog oocytes. Aquatic Toxicology, 75, 380-383.

Зенкевич Г.А. (1992). Гонадотропный гормон рыб: получение и свойства [Fish Gonadotropic Hormone: Isolation and Properties]. Рига, Зинатне. 224 с. (in Russian).

Received 21 December 2010

\section{VARŽU OOCĪTU in vitro NOBRIEŠANAS TESTS KĀ METODE NI2+ TOKSIKOLOG̣ISKĀS IETEKMES NOTEIKŠANAI}

Storu Acipenser güldenstädti Br. gonadotropā hormona (GTH) izteiktā spēja stimulēt varžu Rana temporaria L. oocītu in vitro nobriešanu tika izmantota kā metodiska pieeja $\mathrm{Ni}^{2+}$ toksiskās ietekmes izpētei biotestēšanas sistēmā "Oocīts - GTH". Pētījumā tika izmantoti varžu oocīti ar atškirīgu hormonjutīgumu. Tas l̦āva noskaidrot, ka niḳeḷa joni koncentrācijā 0.1 mg/L paaugstina hormonjutīgumu testoocītos ar sākotnēji zemu hormonjutīgumu, savukārt jona koncentrācijas virs $0.25 \mathrm{mg} / \mathrm{L}$ izsauca izteiktu hormonjutīguma kritumu un pat tā pilnīgu bloḳē̌sanu neatkarīgi no testoocītu sākotnējā hormonjutīguma. Pētījuma rezultāti rāda, ka Ni ${ }^{2+}$ spēj pārtraukt hormona specifisko iedarbību uz hormonjutīgo oocītu un tādējādi būtībā blokēe važu reproduktīvā procesa norisi kopumā. Darbā noskaidrots, ka testa sistēma "Oocīts GTH” ir izmantojama arī kā jutīga metode $\mathrm{Ni}^{2+}$, kā arī citu smago metālu jonu un dažādu ūdens vides piesārṇotāju toksiskās iedarbības pētǐšanai. 